\title{
РЕЗУЛЬТАТИ ПОГЛИБЛЕНОГО АНАЛІЗУ ПАРАМЕТРИЧНИХ ПОКАЗНИКІВ ТЕЛЕРЕКЛАМИ ЛІКІВ, ПАРАФАРМАЦІї, ПИВО-ГОРІЛЧАНИХ ВИРОБІВ - ДОКАЗОВА БАЗА ДЛЯ РОЗРОБКИ НОРМАТИВНО-ПРАВОВИХ ЗАСАД ЕФЕКТИВНОГО ДЕРЖАВНОГО УПОРЯДКУВАННЯ ІІЇ ДІЯЛЬНОСТІ
}

\author{
М. С. Пономаренко, О. С. Соловйов \\ Національна медична академія післядипломної освіти імені П. Л. Шупика

\begin{abstract}
Проведено аналіз параметричних показників моніторингу телереклами лікарських засобів, парафармацевтичної продукції та пиво-горілчаних виробів за 2011 рік на основних телеканалах України. Встановлено ключові відмінності та закономірності розвитку телерекламного бізнесу.
\end{abstract} \\ Ключові слова: фармацевтичне право, законодавство, телерекламні параметри.

\section{РЕЗУЛЬТАТЫ УГЛУБЛЕННОГО АНАЛИЗА ПАРАМЕТРИЧЕСКИХ ПОКАЗАТЕЛЕЙ ТЕЛЕРЕКЛАМЫ ЛЕКАРСТВ, ПАРАФАРМАЦИИ, ПИВО- ВОДОЧНЫХ ИЗДЕЛИЙ - ДОКАЗАТЕЛЬНАЯ БАЗА ДЛЯ РАЗРАБОТКИ НОРМАТИВНО-ПРАВОВЫХ ОСНОВ ЭФФЕКТИВНОГО ГОСУДАРСТВЕННОГО УПОРЯДОЧЕНИЯ ЕЕ ДЕЯТЕЛЬНОСТИ}

\author{
Н. С. Пономаренко, А. С. Соловьев
}

Национальная медицинская академия последипломного образования имени П. Л. Шупика

\begin{abstract}
Методы и объекты исследования. Объектом исследования является реальный мониторинг телерекламы лекарственных средств (ЛС) в эфирном пространстве на основных телеканалах Украины, России, Белоруси. Методы мониторинга базируются на фактическом массиве результатов репрезентативной выборки (сплошного наблюдения), которые обеспечивают валидность результатов доказательной фармации.

Стратегическая цель исследования - установление ежегодных закономерностей в телерекламной деятельности, составление перечня представленных лекарств, парафармации, их ротации, нарушений и мероприятий по созданию нормативно-правовых основ в рекламном бизнесе.

Тактическая цель данного исследования заключается в обобщении параметрических показателей анализа мониторинга телерекламы лекарств, парафармацевтической и пиво-водочной продукции за 2011 год.

Результаты исследования и их обсуждение. Ежегодные темпы роста объемов инвестиций фармкомпаний в телерекламу в денежном выражении (в грн) вырос в 2012 г. по сравнению с 2011 г на $+\Delta 35$,8 \%, в 2013 г в сравнении с 2012 г. на $+\Delta 47,1 \%$.

Одновременно нашими учеными доказано, что индекс роста объемов сбыта лекарственного средства до проведения рекламной компании составлял $10,9 \%$, во время проведения его рекламы - 24,4 \%, после проведения несколько снижался, но, в некотором временном интервале стабильно удерживался до 20,8 \%. Динамика роста объемов сбыта лекарственных средств с участием телевидения (ТВ) и без рекламы на ТВ ярко демонстрируется данными парных сравнительных показателей за 2011 и 2012 годы.

В июне 2014 нами проведены экспериментальные исследования и сравнительный анализ их результатов, в отношении розничных цен рекламируемых и не рекламируемых лекарственных средств, аналогичных по активным фармацевтическим ингредиентам. Эти исследования были проведены на примере Дротаверина (отечественный не рекламируемый ЛП) и Но-шпы (Франция) - широко рекламируемый препарат, стоимость которого в 2-3 раза выше Дротаверина отечественного производителя.

Количество телерекламной продукции, а именно лекарственных средств, в 2011 г. увеличилась на 17,7 \%, а в денежном выражении (грн) составляет $+\Delta 26,8$ \%. Одновременно с увеличением объемов производства увеличиваются и телерекламная ниша, и цена лекарств. Расхождение в разрекламированных и не рекламируемых ЛС превышает, в данном случае, более чем в 2 раза.

Выводы. Проведен анализ параметрических показателей мониторинга телерекламы лекарственных средств, парафармацевтической продукции и пиво-водочных изделий за 2011 год на основных телеканалах Украины. Установлены ключевые отличия и закономерности развития телерекламного бизнеса.
\end{abstract}

Ключевые слова: фармацевтическое право, законодательство, телерекламные параметры.

(C) М. С. Пономаренко, О. С. Соповйов 


\title{
RESULTS OF IN-DEPTH ANALYSIS OF PARAMETRIC INDICES OF TELEVISION ADVERTISING OF MEDICINES, PARAPHARMACY, ALCOHOLIC DRINKS - EVIDENCE BASE FOR THE DEVELOPMENT OF NORMATIVE AND LEGAL PRINCIPLES OF THE EFFECTIVE STATE REGULATION OF ITS ACTIVITY
}

\author{
M. S. Ponomarenko, O. S. Soloviov \\ National Medical Academy of Postgraduate Education by P. L. Shupyk
}

\begin{abstract}
There was conducted the analysis of parametric indices of monitoring of television advertising of medicines, parapharmaceutical production and alcoholic drinks in 2011 on the main Ukrainian television channels. There were determined key differences and mechanisms of the development of television advertising business.
\end{abstract}

Key words: pharmaceutical law, legislation, television advertising parameters.

Вступ. На даному етапі поглибленого аналізу моніторингу телереклами ліків, парафармацевтичної продукції (ПФ+) та пиво-горілчаних виробів (ПГВ) ми звертаємо увагу на доказову фармацію, як науку, що вивчає, у даному випадку, соціально-орієнтовані системи (структури) та її окремі компоненти, підсистеми.

Соціометричні методи, зв'язки та кластерні згуртування, наприклад, цільової аудиторії-це атрибути, які не виділяють окремих членів аудиторної групи, а відтак, складають емерджентні властивості структури групи й мають частіпте негативний вплив на населення України та їх стан здоров'я. Тому, як зазначалося, емерджентні властивості характерні (притаманні) для всього цілого, а не для його складових елементів.

Отже доказова база, в умовах певної невизначеності, потребує всебічного дослідження як параметричних, так і якісних показників телерекламної продукції, що дозволяє встановлювати динаміку, закономірності розвитку подій, явищ позитивного чи негативного впливу на їх розвиток. Зазвичай при вивченні таких структур (систем) широко використовують ієрархічні (лінійні) та фасетні (розгалужені, голкоподібні) методи дослідження. На підставі таких доказів і формується державне адміністративно-деліктне взаємоузгоджене право у сфері обігу ліків, ПФ+, ПГВ, біологічно-активних речовин, дитячого харчування та їх правдивість, доцільність, безпечність й нормативно-правове упорядкування в системі рекламного бізнесу $[1-7,11,13,16-18]$.

Стратегічна мета дослідження - встановлення щорічних закономірностей в телерекламній діяльності, складанні, переліку презентованих ліків, парафармації, ïx ротації, порушень i заходів щодо створення нормативно-правових засад в рекламному бізнесі.
Тактична мета даного дослідження полягає в узагальненні параметричних показників аналізу моніторингу телереклами ліків, парафармацевтичної та пиво-горілчаної продукції за 2011 рік.

Методи та об'єкти дослідження. Об'єктом дослідження $є$ реальний моніторинг телереклами лікарських засобів (ЛЗ) в ефірному просторі на основних телеканалах України, Росії, Білорусі. Методи моніторингу базуються на фактичному масиві результатів репрезентативної вибірки (суцільного спостереження), які забезпечують валідність результатів доказової фармації.

Результати та їх обгговорення. Щорічні темпи зростання обсягів інвестицій фармкомпаній у телерекламу в грошовому вимірі (у грн) виросли у 2012 p., порівняно з 2011 р., на $+\Delta 35,8 \%$, у 2013 р., порівняно з 2012 р., на $+\Delta 47,1 \%$.

Одночасно нашими вченими доведено, що індекс зростання обсягів збуту лікарського засобу до проведення рекламної компанії складав 10,9\%, під час проведення його реклами $-24,4 \%$, після проведення дещо знижувався, але у деякому часовому інтервалі стабільно утримувався до $20,8 \%$. Динаміка зростання обсягів збуту лікарських засобів за участі телебачення (ТБ) та без реклами на ТБ яскраво демонструється даними парних порівняльних показників за 2011 та 2012 рр. (табл. 1-3) [10, 19].

У червні 2014 року нами проведені експериментальні дослідження та порівняльний аналіз їх результатів, відносно роздрібних цін рекламованих і не рекламованих лікарських засобів, аналогічних за активним фармацевтичним інгредієнтом. Ці дослідження були проведені на прикладі Дротаверину (вітчизняний не рекламований ЛЗ) та Но-шпи (Франція) шиироко рекламований препарат, вартість якого у 2-3 рази вища за Дротаверин вітчизняного виробника. 
Таблиця 1. Вплив телевізійної реклами на продажі безрецептурних лікарських засобів (ЛЗ)

\begin{tabular}{|c|c|c|c|c|c|}
\hline \multirow{2}{*}{ Найменування позиції } & \multicolumn{2}{|c|}{2011} & \multicolumn{2}{|c|}{2012} & \multirow{2}{*}{$\begin{array}{c}\text { 3ростання за } \\
\text { рік, \% }\end{array}$} \\
\hline & реалізація ЛЗ & тастка, \% & реалізація Л3 & тастка, \% & \\
\hline \multicolumn{6}{|c|}{ Безрецептурні лікарські засоби (млн упаковок) } \\
\hline Всього, у т.ч.: & 793,0 & 100,0 & 829,9 & 100,0 & 4,6 \\
\hline Не рекламуються на ТБ & 574,4 & 72,4 & 572,7 & 69,0 & $-0,3$ \\
\hline Рекламуються на ТБ & 218,6 & 27,6 & 257,2 & 31,0 & 17,7 \\
\hline \multicolumn{6}{|c|}{ Безречептурні лікарські засоби (млн грн) } \\
\hline Всього & 10685,2 & 100,0 & 12349,5 & 100,0 & 15,6 \\
\hline Не рекламуються на ТБ & 5748,2 & 53,8 & 6091,4 & 49,3 & 6,0 \\
\hline Рекламуються на ТБ & 4937,0 & 46,2 & 6258,1 & 50,7 & 26,8 \\
\hline
\end{tabular}

3 даних таблиці 1 видно, що кількість телерекламної продукції, а саме лікарських засобів, в 2011 р. збільшилась на $17,7 \%$. А у грошовому виразі (грн) складає $+\Delta 26,8 \%$. Одночасно, зі збільшенням обсягів виробництва, збільшуються й телерекламна ніша та ціна ліків. Розбіжність показників розрекламованих і не рекламованих ЛЗ у даному випадку більша ніж у 2 рази (табл. 2).

Таблиця 2. Вплив телевізійної реклами на зростання середньої ціни безрецептурних лікарських засобів (в грн)

\begin{tabular}{|c|c|c|c|}
\hline $\begin{array}{c}\text { Найменування } \\
\text { позиціі }\end{array}$ & $2011 \mathrm{p}$. & $2012 \mathrm{p}$. & $\begin{array}{c}\text { Зростання } \\
\pm \Delta, \%\end{array}$ \\
\hline Не рекламуються & 10,01 & 10,64 & 6,29 \\
\hline Рекламуються & 22,58 & 24,33 & 7,75 \\
\hline
\end{tabular}

Дані таблиці 2 яскраво засвідчують як зростання рівня телерекламної активності, так і фактичний вплив на збільшення середньої ціни на безрецептурні лікарські засоби. Така різниця у 2011-2012 рр. складала: 225,6 \% та 228,7 \% відповідно. Ці дані підтверджуються й на прикладі середньої вартості рекламованого й не рекламованого Дротаверину (223,3 \% та 225,7 \% відповідно (табл. 3)).

Таблиця 3. Ексклюзивний аналіз середньої вартості таблетки дротаверину (в грн)

\begin{tabular}{|c|c|c|c|}
\hline $\begin{array}{c}\text { Найменування } \\
\text { позиції }\end{array}$ & $2011 \mathrm{p}$. & 2012 р. & $\begin{array}{c}\text { Зростання } \\
\pm \Delta, \%\end{array}$ \\
\hline Не рекламуються & 0,30 & 0,35 & 16,67 \\
\hline Рекламуються, & 0,67 & 0,79 & 17,91 \\
\cline { 2 - 4 } зіставлення цін, $\%$ & 223,33 & 225,71 & 1,06 \\
\hline
\end{tabular}

За 2013 рік частка реклам у вартості препарату складала близько $12 \%$. Саме тому багато європейських та інших розвинутих країн світу, наприклад, Швейцарія, Бельгія заборонили будь-яку рекламу ЛЗ. У Канаді заборонено рекламу ЛЗ на телебаченні і радіо, а в Німеччині її жорстко регламентують і контролюють [19].

Аналіз телереклами ліків багатьох країн світу та наші переконливі докази були реалізовані шляхом введення доповнень до основного Закону України "Про рекламу" [7]. Одночасно введені обмеження телереклами щодо окремих безрецептурних ЛЗ та умов їх презентації у телеефірі. На підставі узагальненої доказової бази щодо недоцільності, а інколи шкоди та загрозливих наслідків були обгрунтовані докази та внесені пропозиції шодо кількісного обмеження й заборони з $2014-2015$ року телереклами ліків й окремої парафармацевтичної продукції, що імітується під ліки. Проведення моніторингу телереклами пиво-горілчаних виробів буде покладено в основу висновку щодо заборони їх реклами у 2015 p. як у телеефірі, на радіо, так і в засобах масової інформації. Як приклад, потужне протистояння проти куріння в усьому світі примусило й в Україні прийняти спеціальний закон і покласти край рекламній пропаганді тютюнових виробів $[8,12,21-30]$.

Результати аналізу параметричних показників постійного моніторингу динаміки обсягів, активності телереклами лікарських засобів (ЛЗ) та парафармацевтичної продукції (ПФ+) за 2004-2010 рр., проведеного спільно з науковцями кафедри організації і економіки фармації Національної медичної академії післядипломної освіти імені П. Л.Шупика, які наведені у таблицях 4 i 5 , дозволили довести встановлені закономірності та тенденції розвитку телерекламного бізнесу з презентації ЛЗ та ПФ+. Зокрема встановлена закономірність посезонної, номенклатурноасортиментної експозиції на окремих телеканалах, їх активність у будні та вихідні.

На вибірковому етапі проведення дослідження та спрощеного формату інтерпретації результатів моніторингу телерекламної, радіорекламної продукції презентованих у теле-, радіоефірі ЛЗ, слід підкреслити означену закономірність й автентичність дизайну 
Таблиця 4. Зведений аналіз параметричних показників постійного моніторингу телереклами лікарських засобів (ЛЗ) та парафармацевтичної продукції (ПФ+) за 2004-2010 pp.*

\begin{tabular}{|l|c|c|c|c|c|}
\hline \multirow{2}{*}{ Назва позиції } & \multicolumn{5}{|c|}{$2004-2010$ pp. } \\
\cline { 2 - 6 } & $2004-2007$ & 2008 & 2009 & 2010 & Всього \\
\hline Кількість назв ЛЗ, ПФ+ & 332 & 183 & 176 & 192 & 710 \\
\hline Кількість виходів у телеефір & 826 & 1898 & 1651 & 1598 & 5973 \\
\hline Кратність (частота) повторюваності & 2,5 & 10,4 & 9,4 & 8,3 & 8,4 \\
\hline
\end{tabular}

Примітка: * спільне дослідження проведено разом з науковцями кафедри організапії̈ і економіки фармапії НМАПО імені П. Л. Шупика.

аудіо- і відеоряду як у теле-, так і в радіоефірі. Однак, з даних таблиці 5 видно, що при фактично однаковій кількості товарних назв у різних лікарських формах та дозуванні, наприклад, на каналах INTER та НТН(138 та 139 найменувань - відповідно), спостерігається непомітна у першому парному порівнянні кількісна відмінність частоти виходів в ефір (390 - INTER та 553 - HTH) або 4,3 найменування за 1 годину та 3,5 - відповідно (138;32 та 139:40).
Слід зазначити, що до 2012 року параметричні показники аналізу результатів моніторингу телереклами в основному здійснювалися на аналізі кількісних, а не якісних показників. 32012 року спостереження проводилось на складніших умовах: фіксування тривалості одиниці виходу у с, фіксування усієї номенклатури загальної реклами та пиво-горілчаної продукції (ПГП) на основних телеканалах України, Росії, Білорусі.

Таблиця 5. Аналіз параметричних показників телереклами лікарських засобів та парафармації за 2011 рік

\begin{tabular}{|l|l|c|c|c|c|c|c|}
\hline \multirow{2}{*}{ Показники } & \multicolumn{5}{c|}{ Назва телеканалу } & Всього за \\
2011 рік
\end{tabular}

Примітка: РК - рекламний коридор: загальний обсяг реклами у телеефірі; РБ - рекламний блок: обсяг реклами лікарських засобів та парафармацевтичної продукції у рекламному коридорі (РК); РВ -рекламне вікно: окремо виділена питома вага ЛЗ та ПФ+ в телерекламному блоці.

Так, рекламний коридор до загального телеефіру HTH складає 23,0 \% (22,3\% - INTER). Рекламний блок лікарських засобів і парафармацевтичної продукції у рекламному коридорі - 32,9 \% (INTER $27,8 \%$ ). Одночасно рекламний коридор у цих парних порівняльних числових та відносних показниках має малопомітні розбіжності у тривалості рекламного коридору в одночасовому інтервалі $(13,4$ та 13,8 хв відповідно).

Вибірковий огляд різних телеканалів щодо рекламної презентації у телеефірі лікарських засобів і парафармації показав, що найбільший інтерес для моні- торингу представляють канали: ICTV, INTER, HTH у співставленні з СТБ, ТРК “Україна”. У 2011 році ми звернули увагу на появу реклами пиво-горілчаних виробів, потім на розгортання телерекламного захоплення екстрасенсами, ворожками тощо. Ці безмедикаментозні й безконтактні спроби лікування (передбачення та позбавлення) всіляких вад включалися до програмних телепередач.

На наступному етапі (табл. 6) наведено моніторинг презентації лікарських засобів відносно загального ефіру та співвідношення питомої ваги у рекламному коридорі (загальному рекламному часі). 
Таблиця 6. Порівняльний аналіз якісних показників телерекламного вікна лікарських засобів у телерекламному коридорі за 2011 рік

\begin{tabular}{|c|c|c|c|c|c|c|c|}
\hline \multirow{2}{*}{\multicolumn{2}{|c|}{ Показники }} & \multicolumn{5}{|c|}{ Назва телеканалу } & \multirow{2}{*}{$\begin{array}{c}\text { Всього за } \\
2011 \text { рік }\end{array}$} \\
\hline & & ICTV & INTER & $\mathrm{HTH}$ & СТБ & ТРК Україна & \\
\hline \multicolumn{2}{|c|}{ Телереклама Л3, $\Sigma$ с } & 2655 & 3850 & 5395 & 10625 & 2139 & 24664 \\
\hline \multicolumn{2}{|l|}{ Найменувань } & 75 & 97 & 96 & 166 & 63 & 497 \\
\hline \multicolumn{2}{|l|}{ Виходів } & 162 & 280 & 368 & 617 & 108 & 1535 \\
\hline \multirow[t]{2}{*}{ Один вихід, с } & Л3 & 16,4 & 13,8 & 14,7 & 17,2 & 19,8 & 16,1 \\
\hline & $\Pi \Phi+$ & 26,8 & 29,9 & 29,8 & 22,5 & 23,1 & 26,1 \\
\hline
\end{tabular}

Як видно з даних таблиці 6, кількість найменувань на каналах INTER і HTH також мають, як і у попередньому аналізі, рівнозначну величину (97 та $96-$ відповідно), разом з тим помітно різняться за частотою виходів у телеефір (280 та 368 одиниць). Отже й презентація одного виходу в телерекламний ефір складає 14,7 с (13,8 c - INTER).

Слід підкреслити, що міжнародним умовно визначеним стандартним виміром утримання "в кадрі" телерекламної одиниці, вважається 30 с. Більшість дослідників, враховуючи трудомісткість фіксування рекламної одиниці виміру часу, беруть саме середньовизначений показник - 30 с. Такий підхід у нашому випадку призводить до $50 \%$ похибок, а тому $\epsilon$ неприйнятним. Нашим дослідженням доведено, що протяжність у часовому вимірі середньозваженої одиниці презентації лікарського засобу складає в с: 16,$4 ; 13,8 ; 14,7 ; 17,2 ; 19,8$ (ICTV, INTER, HTH, СТБ, TPК відповідно). Середньоарифметичне значення цього показника по усіх каналах складає 16,1 с. Доречно підкреслити також, що більшість менеджерів з рекламного бізнесу вважають найприйнятнішою i, навіть ефективнішою рекламу, якшц вона виходить в ефір і утримується $\pm 14-17$ секунд.

Одночасно достовірно встановлено, що умовний стандарт презентації одиниці парафармацевтичної (ПФ+) продукції відповідає міжнародним стандартним нормам, тобто максимально наближається до 30 секунд експозиції (тривалості) (табл. 7). Середньозважена тривалість утримання виходу (ПФ+): 26,8 c, 29,9 c, 29,8 c, 22,5 c, 23,1 с (відповідно).

Таблиця 7. Поглиблений аналіз якісних показників телерекламної ніші парафармацевтичної та іншої продукції у телерекламному коридорі за 2011 рік

\begin{tabular}{|c|c|c|c|c|c|c|c|}
\hline \multirow{2}{*}{\multicolumn{2}{|c|}{ Показники }} & \multicolumn{5}{|c|}{ Назва телеканалу } & \multirow{2}{*}{$\begin{array}{c}\text { Всього за } \\
2011 \text { рік }\end{array}$} \\
\hline & & ICTV & INTER & $\overline{\mathrm{HTH}}$ & СТБ & ТРК Україна & \\
\hline \multicolumn{2}{|c|}{ Телереклама $П \Phi+, \Sigma$ c } & 1850 & 3290 & 5510 & 5690 & 1591 & 17931 \\
\hline \multicolumn{2}{|c|}{ Найменувань } & 38 & 41 & 43 & 60 & 31 & 213 \\
\hline \multicolumn{2}{|l|}{ Виходів } & 69 & 110 & 185 & 253 & 69 & 686 \\
\hline \multirow[t]{3}{*}{ Один вихід, с } & $\Pi \Phi+$ & 26,8 & 29,9 & 29,8 & 22,5 & 23,1 & 26,1 \\
\hline & Л3 & 16,4 & 13,8 & 14,7 & 17,2 & 19,8 & 16,1 \\
\hline & ЛЗ ПФ+ & 19.5 & 18,3 & 19.7 & 18.7 & 25.1 & 19,2 \\
\hline
\end{tabular}

Середньоарифметичний показник по усіх узятих для проведення моніторингу телеканалах України складає 26,1 с. Одночасно слід зазначити, що у телеефірі Росії, Білорусі в основному перериваються програмні передачі анонсами і зовсім рідко ЛЗ, рекламний коридор яких коливається 2-4 хв у годину.

Як видно з даних таблиц 1-7, показники кількісних i якісних значень на деяких телеканалах, їх основні та інтегральні параметри мають майже $100 \%$ схожість. Збіг отриманих результатів не $є$ випадковим, а засвідчує той факт, що асортиментний масив і перелік найменувань, їх параметри, в сутності, повторюються у аутотентичному форматі, дизайні та змісті. Така закономірність спостерігається й для те- лерекламної парафармацевтичної продукції та середньозважених показників утримання одиниці виходу у розрахунку на ЛЗ ПФ+ разом взяті $(19,5 \mathrm{c}, 18,3 \mathrm{c}$, 19,7 с, 18,7 c, 25,1с). Середньоарифметична тривалість в ефірі одиниці виходу ЛЗ ПФ + по усіх каналах, узятих для проведення моніторингу, складає $19,2 \mathrm{c}$.

3 появою телереклами пиво-горілчаних виробів (ПГВ), яка стала помітною з 2011 року та різко зросла у 2012-2014 роках, нами проведено аналіз рекламної ніші, яку займають ПГВ (табл. 8).

Як видно з даних таблиці 8, ще у 2011 році висока телерекламна активність спостерігалася на телеканалі ICTV. Така тенденція з наростанням презентації 
Таблиця 8. Результати вибіркового аналізу кількісних і якісних показників телереклами пиво-горілчаних виробів у $2011 \mathrm{p}$.

\begin{tabular}{|c|c|c|c|c|c|c|c|}
\hline \multirow{2}{*}{\multicolumn{2}{|c|}{ Показники }} & \multicolumn{5}{|c|}{ Назва телеканалу } & \multirow{2}{*}{$\begin{array}{c}\text { Всього } \\
(2011 \text { р.) }\end{array}$} \\
\hline & & ICTV & INTER & HTH & СТБ & ТРК УКРАЇНА & \\
\hline \multicolumn{2}{|c|}{ Ємність ніші ПГВ, с } & $1397^{*}$ & $450 * *$ & $810 * *$ & $1440^{* *}$ & 450 & 4547 \\
\hline \multicolumn{2}{|c|}{ Найменувань } & 11 & 6 & 4 & 7 & 6 & 47 \\
\hline \multicolumn{2}{|c|}{ Виходів (аудіо) } & 42 & $15 * *$ & $27 * *$ & $48 * *$ & 13 & 145 \\
\hline \multicolumn{2}{|c|}{ Одиниць вих. ПГВ, \% } & 30,0 & $30,0 * *$ & $30,0^{* *}$ & $30,0 * *$ & 534,6 & 26,3 \\
\hline \multirow{2}{*}{$\begin{array}{l}\text { Смність ЛЗ } \\
П Ф+, \text { ПГВ }\end{array}$} & $\mathrm{c}$ & 5902 & 7590 & 11715 & 17755 & 4180 & 47142 \\
\hline & $\%$ & 35,9 & 29,6 & 35,3 & 30,5 & 28,1 & 31,8 \\
\hline
\end{tabular}

Примітки: * пиво+горілчані вироби /аудіо та відео презентація; ** пиво-вироби (аудіо-презентація).

ПГВ стрімко активізувалася у 2012-2014 рр. Так, ємність ПГВ на цьому каналі (1397 с) перевищує INTER та HTH разом узяті $(450+810=1260 \mathrm{c})$. Кількісний показник за виробником ПГВ показав, що у 2011 році, окрім ICTV, був небагаточисленно представлений. Разом з тим, на ICTV наприклад, було представлено 11 марками пива та досить чисельною кількістю виходів у телеефір (табл. 9).

Таблиця 9. Асортиментний перелік найменувань телерекламної пиво-горілчаної продукції, презентованої у телеефірі у 2011 р. (відбірково)

\begin{tabular}{|c|c|c|c|c|c|c|c|c|}
\hline \multirow{2}{*}{ № по3. } & \multirow{2}{*}{$\begin{array}{c}\text { Найменування } \\
\text { рекламної } \\
\text { продукції (ПГВ }) \\
\end{array}$} & \multirow{2}{*}{$\begin{array}{l}\mathrm{t}=1 \\
\text { екз. } \\
\text { поз. }\end{array}$} & \multicolumn{5}{|c|}{ Назва телеканалу } & \multirow{2}{*}{$\begin{array}{c}\text { Всього } \\
\text { (2011 p.) }\end{array}$} \\
\hline & & & ICTV & INTER & HTH & СТБ & ТРК Україна & \\
\hline \multicolumn{9}{|c|}{ Пиво } \\
\hline \multirow[t]{2}{*}{1} & \multirow[t]{2}{*}{ Чернігівське } & 20 & 3 & - & - & - & - & 3 \\
\hline & & 30 & 8 & 2 & 11 & 17 & 4 & 42 \\
\hline 2 & Львівське & 30 & 4 & - & 8 & 4 & - & 16 \\
\hline 3 & Рогань & 30 & 6 & 2 & 4 & 6 & - & 18 \\
\hline 4 & 433 & 30 & 4 & 2 & - & 2 & 1 & 9 \\
\hline 5 & Оболонь & 30 & 2 & 4 & - & - & 3 & 9 \\
\hline 6 & Білий лев & 30 & 5 & 4 & - & - & 1 & 10 \\
\hline 7 & Жадецький гусь & 30 & 3 & - & - & 7 & - & 10 \\
\hline \multirow[t]{2}{*}{8} & \multirow[t]{2}{*}{ Балтика } & 07 & 1 & - & - & - & - & 1 \\
\hline & & 30 & 2 & - & 4 & 7 & 2 & 15 \\
\hline 9 & Старопрамен & 30 & 2 & - & - & - & 2 & 4 \\
\hline 10 & Славутич & 30 & 1 & - & - & - & - & 1 \\
\hline 11 & Карлінг & 30 & 1 & - & - & - & - & 1 \\
\hline 12 & Челсі & 30 & - & 1 & - & - & - & 1 \\
\hline 13 & Тібор & 30 & - & - & - & 5 & - & 5 \\
\hline \multirow{2}{*}{$\begin{array}{l}\text { Всього } \\
\text { (пиво) }\end{array}$} & Найменувань & 13 & 11 & 6 & 4 & 7 & 6 & 34 \\
\hline & Виходів & 145 & 42 & 15 & 27 & 48 & 13 & 145 \\
\hline \multicolumn{9}{|c|}{ Горілчані вироби } \\
\hline \multirow[t]{2}{*}{14} & \multirow[t]{2}{*}{ Горілочка } & 05 & - & - & - & 15 & - & 15 \\
\hline & & 10 & 10 & - & - & 8 & - & 18 \\
\hline \multirow[t]{3}{*}{15} & \multirow[t]{3}{*}{ Неміров } & 0 & - & - & - & $(10)$ & - & - \\
\hline & & 05 & - & - & - & 15 & - & 15 \\
\hline & & 10 & 4 & - & - & 9 & - & 13 \\
\hline \multirow[t]{3}{*}{16} & \multirow[t]{3}{*}{ Хортиця } & 0 & (6) & - & - & (9) & - & - \\
\hline & & 05 & - & - & - & - & 2 & 2 \\
\hline & & 10 & 8 & 6 & - & 8 & 5 & 27 \\
\hline \multirow{2}{*}{$\begin{array}{c}\text { Всього } \\
\text { (горілчані } \\
\text { вироби) } \\
\end{array}$} & Найменувань & 3 & 3 & 1 & - & 3 & - & 7 \\
\hline & Виходів & 90 & 22 & 6 & - & 55 & 7 & 90 \\
\hline \multirow{2}{*}{$\begin{array}{c}\text { PA3OM } \\
\text { ПГВ } \\
\end{array}$} & Найменувань & 16 & 14 & 7 & 4 & 10 & 6 & 41 \\
\hline & Виходів & 235 & 64 & 21 & 27 & 103 & 20 & 235 \\
\hline
\end{tabular}


На наступних часових етапах моніторинг специфічної телерекламної продукції ми ускладнювали. Так, у 2012 році моніторинг здійснювався для порівняння показника активності у будні та вихідні дні. У 2013 році для запобігання похибкам проведено суцільний аналіз за єдиним принципом. А саме: телереклама здійснювалася з 8.00 до 24.00 (тобто впродовж 16 годин підряд). Одночасно проведено аналіз телепрограмної продукції, інформаційно-довідкового, просвітницького, морально-етичного характеру.

Тотальне телерекламне навантаження яскраво демонструється даними, які містяться у таблиці 10.

Таблиця 10. Частота виходів телерекламної продукції на одну годину ефірного часу у 2011 році

\begin{tabular}{|l|c|c|c|c|c|c|}
\hline \multirow{2}{*}{$\begin{array}{c}\text { Середньозважений показник } \\
\text { телереклами }\end{array}$} & \multicolumn{5}{|c|}{ Назва телеканалу } & \multirow{2}{*}{$\begin{array}{c}\text { Всього за } \\
2011 \text { рік }\end{array}$} \\
\cline { 2 - 6 } & ICTV & INTER & HTH & СТБ & ТРК Україна & 4,3 \\
\hline Кількість найменувань за 1 год & 5,9 & 4,3 & 3,5 & 4,0 & 4,9 & 13,4 \\
\hline Кількість виходів за 1 год & 12,1 & 12,2 & 13,8 & 15,5 & 9,3 & 3,1 \\
\hline Кратність повторень & 2,0 & 2,8 & 3,9 & 3,8 & 1,9 & 24,8 \\
\hline Смність РК до загального ефіру, \% & 24,0 & 22,3 & 23,0 & 28,8 & 21,8 & 2 \\
\hline
\end{tabular}

Так, лише на п'яти каналах за одну годину нав'язливо пропагується і представляється 13,4 виходи лікарських препаратів та парафармацевтичної продукції.

\section{Лiтература}

1. Броуэр Луи Фармацевтическая и продовольственная мафия / Луи Броуэр. - К. : Изд-во “Княгиня Ольга”, 2002. $280 \mathrm{c}$.

2. Васкес Абанто Х. Э. Медицина и закон в Украине / Х. Э. Васкес Абанто // Медичні та фармацевтичні науки: аналіз сучасності та прогноз майбутнього : зб. матер. міжнар. наук.-прак. конф. - Дніпропетровськ, 1-2 листопада 2013 р. - С. $6-12$.

3. Васкес Абанто Х. Э. Медицинская деятельность и законодательство страны / Х. Э. Васкес Абанто // Новости медицины и фармации. - 2013. - С. 17.

4. Васкес Абанто Х.Э. Реформа здравоохранения в Украине глазами практического врача / Х. Э. Васкес Абанто // Медична наука та медична практика в Україні: проблеми розвитку та взаємодії : зб. тез наук. робіт учасників міжнар. наук.-практ. конф. - Одеса, 8-9 листопада 2013 р. - С. 108 112.

5. Васкес Абанто Х.Э. Реформирование здравоохранения и права медика / Х. Э. Васкес Абанто // Современная медицина: актуальные вопросы // Сб. статей по матер. XXV междунар. науч.-практ. конф. - № 11, 18 ноября 2013 г. Новосибирск : СибАК.-С. 84-92.

6. Інформаційне забезпечення якості лікарських засобів під час оптової та роздрібної реалізації у фармацевтичних періодичних виданнях / Н. О. Ветютнева, М. С. Пономаренко В. В. Трохимчук [та ін.] // Зб. наук. праць співроб. НМАПО ім. П. Л. Шупика. - К., 2007. - Вип. 16, кн. 1. - С. 555-559. 7. Про рекламу Закон України № 270/96-ВР від 03.07.1996 p. / Відомості Верховної Ради України, 1996. - № 39; 2004 . № 8; 2005. - № 52; 2006. - № 5-6, № 31; 2007. - № 34; 2008. - № 18. - [Електронний ресурс]. - Режим доступу: http:// zakon3.rada.gov.ua/laws/show/270/96-вр
Висновки. Проведено аналіз параметричних показників моніторингу телереклами лікарських засобів, парафармацевтичної продукції та пиво-горілчаних виробів за 2011 рік на основних телеканалах України, встановлені ключові відмінності та закономірності розвитку телерекламного бізнесу.

8. Кукес В. Г. Варениклин - препарат нового поколения для лечения табачной зависимости / В. Г. Кукес, В. Ф. Марннин, В. В. Гаврисюк // Клин. фармакол. и тер. - 2009. - № 18. - C. $1-5$.

9. Куталиев А. // Эффективность рекламы : 2-е издание.М. : Изд-во Эксмо, 2006. -416 с.

10. Мнушко 3. Н. Оценка коммуникативной и экономической эффективности рекламы лекарственных средств / 3. Н. Мнушко, И. П. Левченко, А. Б. Ольховская // Прови3ор. - 2007. - № 15. - С. 3-7.

11. Нагорна О. О. Резолюція третьої науково-практичної конференції "Безпека та науково-правовий супровід лікарських засобів: від розробки до медичного застосування"/ О. О. Нагорна, О. В. Матвєев // Ваше здоров'я. -2013. -№ 45-46. - С. 23 .

12. Современные принципы медикаментозного лечения табакокурения и никотиновой зависимости / Г. В. Погосова, Н. М. Ахмеджанов, Н. П. Качанова, И. Е. Колтунов // Профилакт. мед. - 2009. - № 5.- С. $29-34$.

13. Історичні етапи розвитку інформаційної роботи та презентації лікарських засобів і сучасні підходи щодо введення фармацевтичного продукту на споживчий ринок України. Дотримання етичних засад промоції та реклами. Повідомлення 1 / М. С. Пономаренко, М. Л. Сятиня, А. А. Баб́ський [та ін.] // Фармац. журн. - 2007. - № 4. C. $10-16$.

14. Небезпечний пиво-горілчаний СПРУТ (система просування й реклами українських товарів) у телерекламному просторі - реальна загроза здоров'ю народу України / М. С. Пономаренко, Г. В. Загорій, О.М.Тернова [та ін.] // Фармац. журн. - 2013. - № 1.- С. 3-7. 
15. Пономаренко М. С. Рекламний тероризм. Параметричний, парафармацевтичний та пиво-горілчаний телеефірний спрут - реальна загроза здоров'ю української нації // Ваше здоров'я. - 2012. - № 2.-- С. 11.

16. Соловйов О. С. Системна стратегія і тактика законотворчого процесу розвитку фармації в Україні/ О. С. Соловйов // Зб. наук. праць співроб. НМАПО ім. П. Л. Шупика. - К., 2013. - Вип. 22, кн. 4.- С. 408-413.

17. Соловйов О. С. Держслужба України продовжить курс на імплементацію європейського законодавства до вітчизняного / О. С. Соловйов // Фармацевт практик. - 2013. № $12 .-$ C. 9 .

18. Соловьев А.С. Регуляторная политика в фармацевтической отрасли: проблемы и пути их решения / А. С. Соловьев // Еженедельник АПТЕКА. - 2014. - № 3.-С. 7.

19. Реклама ліків, або смертельна епідемія самолікування.Дані дослідження ринку Pharm Xplorer ${ }^{\mathrm{TM}}$ компанії Proxima Pesearch // Ваше здоров'я. - 2013. - № 37-38. - С. 4-5.

20. Шампурін О. В. Методичні вказівки : Основи наукових досліджень / О. В. Шампурін, І. М. Попова.-Одеса : ОНПУ, 2002. $-24 \mathrm{c}$.

21. Americans'Use of Dietary Supplements that's are potentially Harmfuiln CKD/Vanessa Grubbs, Laura C., Plantinga [et al.] // Am. J. Kidney. Dis. - 2013. - Vol. 61. - P. 739-747.

22. Boffetta P. Involuntary smoking and lung cancer/ P. Boffetta // Scand. J. of Work, Environmtnt and Health. 2012. - Vol. 28, № 2. - P. 30-40.
23. LancasterT. Individual Behavioral counseling for smoking cessation / T. Lancaster, L. F. Stead // Cochrane Database Syst. Rey. -2005 . - P.4.

24. Varencline reduces alcohol self-administration in heavydrinking smokers / S. A. McKee, E. L. R. Harrison, S. S. O'Malley [et.al.] // Biol. Psychiat. - 2009. - Vol. 66. - P. 185-190.

25. McClave A. K. Smoking Characteristics of Adults Witt Selected Lifetime Mental III nesses: Results From the 2007 National Health Interview Survey/A. K. McClave//Am. J. of Public Health. - 2010. - Vol. 100. - P. 12.

26. Effect of exposure to secondhand smoke on markers of inflammation: the ATTICA study / D. B. Panagiotakos, C. Pitsavos, C. Chrysohoou [et al.] // Am. J. of Medicine. 2009. - Vol. 116. - № 3. - P. 145-150.

27. Rigotti N.A. The future of tobacco treatment in the health care system/N.A. Rigotti//Ann. Int. Med.-2009. - Vol. 150. -P. 496-497.

28. Cigarette smoking and cognitive decline / N. Thompson, M. Richards, M. J. Jarvis, M. E. Wadsworth // Am. J. Public Health. -2005. - Vol. 95.-P. 324-328.

29. Tonstad S. Effect of maintenance therapy with varepicline on smoking cessation: a randomized controlled trial/ S. Tonstad, P. Tonnesen, P. Hajek [et al.] // JAMA. - 2006. Vol. 296.-P. 64-71.

30. Wagena E. J. Should nortriptyline be used as a first-line aid to help smokers quit? Results from a systematic review and meta-analysis / E. J. Wagena, P. Knipschild, M. P. Zeegers // Addiction. - 2005.- Vol. 100.--P. 317-326. 